UDC 543.58.062:546.881

\title{
RESEARCH INTO COMPLEX FORMATION OF COBALT(II) AND NICKEL (II) WITH 2-HYDROXY-5-NITROTHIOPHENOL AND DIPHENYLGUANIDINE
}

\author{
S.G. Aliyev ${ }^{1}$, R.A. Ismailova ${ }^{1}$, Sh.A. Ibrahimova ${ }^{2}$, \\ Z.G. Asgerova ${ }^{3}$, A.Z. Zalov ${ }^{3}$ \\ ${ }^{1}$ Azerbaijan State University of Oil and Industry, \\ Department of Chemistry and Technology of Inorganic Substances, \\ Azadlyg Ave., 16/21, AZ 1000, Baku, Azerbaijan \\ ${ }^{2}$ Baku State University, \\ Zahid Khalil str., 23, AZ 1148 Baku \\ ${ }^{3}$ Azerbaijani State Pedagogical University \\ Uz. Hadjibekov str., 68, AZ 1000 Baku \\ e-mail: zalov1966@mail.ru
}

Received 09.03.2018.

\begin{abstract}
The interaction of cobalt (II) and nickel (II) with 2-hydroxy-5-nitrothiophenol (HNTPh) and diphenylguanidine (DPG) produces chloroform-extracted mixed-ligand complexes (MLC) with the ratio Me (II): GNTF: $D P G=1: 2: 2$. Conditions for extraction-photometric determination of cobalt (II) nickel (II) are revealed. It found that MLC are formed in a weakly acid medium ( $p H_{\text {opt }}$ $=4.4 \div 7.8$ ). Note that all studies were performed with $\mathrm{CHCl}_{3}$ (extraction ratio $\mathrm{R}=98.3-98.6 \%$ ). To generate and extract MLC, (1.2-2.0) × 10-3 M HNTPh and (2.0-2.5) × 10-3 M DPG are required. Maximum in the absorption spectrum for cobalt (II) nickel (II) MLC is observed at 560 $\mathrm{nm}$ and $480 \mathrm{~nm}$, respectively. The following chemical analytical parameters were calculated: extraction constants (Kex $=10.56-11.64)$, stability constants $(\beta=8.59-9.62)$, distribution constants $\left(K_{D}=1.86-1.92\right)$, coefficients extraction $(R=98.3-98.6 \%)$ with molar coefficient of light absorption being equal to $(2.64-3.30) \times 104$.

Key words: cobalt, nickel, 2-hydroxy-5-nitrothiophenol, diphenylguanidin, chlorophorm
\end{abstract}

\section{INTRODUCTION}

Many metal ions form colored binary particles with hydroxythiophenols, such as 2hydroxy-5- halogenthiophenols (HTPh) and 2,6-dithophenols (DTPh) [1,2]. Besides, the color and extraction properties of these species can be improved by adding auxiliary compounds [3-4]. The following ionassociated reagents were used for liquid liquids extraction of $\left[\mathrm{X}(\mathrm{HTPh})_{2}\right]^{\mathrm{z}-}$ or $\left[\mathrm{X}(\mathrm{DTPh})_{2}\right]^{\mathrm{z}-}(\mathrm{z}=2$ or 3 ; X-metal): Aromatic Amines \{aniline, N-methylaniline, N,Ndimethylaniline, $o$-toluidine, $m$-toluidine, $p$ toluidine, 3,4-xylidine, 2,4-xylidine, and 2,5- xylidine [5-14], diphenylguanidine and triphenylguanidine [15], diphenylamine and triphenylamine [16]. The previous article dealt with the formation and extraction of the complex in a system containing Co (II) and $\mathrm{Ni}$ (II), 2-hydroxy-5-iodothiophenol (HITP), diphenylguanidine (DPG) and triphenylguanidine (TPG) [17].

Below-cited are results of systematic research into a similar extraction chromogenic system which involves 2-hydroxy-5nitrothiophenol (HNTPh) in place of HITP. 


\section{MATERIALS AND METHODS}

Reagents and instruments. The initial solution of Ni (II) and Co (II) was prepared through dissolving $\mathrm{NiCl}_{2} \times 6 \mathrm{H}_{2} \mathrm{O}$ and $\mathrm{Co}\left(\mathrm{NO}_{3}\right)_{2} \times 6 \mathrm{H}_{2} \mathrm{O}$, respectively, in distilled water. Process solutions of Me (II) $\left(0.1 \mathrm{mgL}^{-1}\right)$ were prepared by appropriate dilution of the stock solution. The concentration of cobalt and nickel solutions was adjusted gravimetrically [18].

HTPh was synthesized according to the procedure [19]. Chloroform solutions of HTPh (0.01 $\left.\mathrm{mol} \mathrm{L}^{-1}\right)$ and DPG $\left(0.025 \mathrm{~mol} \mathrm{~L}^{-1}\right)$ were used. To create the optimum acidity, $0.1 \mathrm{~mol}$ $\mathrm{L}^{-1}$ solutions of $\mathrm{HCl}, \mathrm{NaOH}$, or ammonium acetate $\left\{\mathrm{CH}_{3} \mathrm{COOH}+\mathrm{CH}_{3} \mathrm{COONH}_{4}(\mathrm{pH} 4-12)\right\}$ buffers were applied.

The absorbance of the extracts was measured through the use of a SF 26 spectrophotometer and KFK 2 photocolorimeter. Glass cells with optical paths of 5 to $10 \mathrm{~mm}$ were used. $\mathrm{pH}$ of aqueous phase was measured using an I-120.2 potentiometer with a glass electrode.

\section{RESULTS AND DISCUSSION}

At $\mathrm{pH}$ 5-6, the cobalt and nickel complex $\{\mathrm{Me}-\mathrm{HNTPh}-\mathrm{DPG}(\mathrm{Me}=\mathrm{Co}$ or $\mathrm{Ni})\}$ is not extracted with the help of inert organic solvents. To determine signs of complex charge, ion exchange chromatography was used: AV17 anionexchanger in chloroform absorbs a part of solution; the chromatographic column is coloured in orange while $\mathrm{Ni}$ (II) and Co (II) are not detected in the filtrate. The anion complex is extracted in the presence of a hydrophobic amine, wherein the complex stability increases, and the colour becomes more saturated. To neutralize the charge of the anion complex, diphenylguanidine is used as a hydrophobic amine which transforms into a diphenylguadininic ion in the acidic medium, that is,

$$
\begin{gathered}
\left(\mathrm{C}_{6} \mathrm{H}_{5} \mathrm{NH}\right)_{2} \mathrm{C}=\mathrm{NH}+\mathrm{H}^{+} \\
(\mathrm{DPG})
\end{gathered}
$$

Influence of $\mathrm{pH}$ of the aqueous phase. The spectra of mixed ligand complexes (MLC) Me (II)-HNTPh-DPG extracted in chloroform are shown in Fig.1. The light absorption spectra of Me (II) complexes with HNTPh and DPG were studied in a wide range of medium $\mathrm{pH}$. Complexes of cobalt and nickel are formed and extracted at $\mathrm{pH}$ 2.2-8.4 and 2.5-10.8, respectively. It could be seen that Co(II)- HNTPh - DPG species are extracted to a greater extent at $\mathrm{pH}$ values in the range of 5.5-7.8. $\mathrm{Ni}(\mathrm{II})$ complexes are extracted at lower $\mathrm{pH}$ : 4.4-6.7.

Choice of Extractant. To extract the complexes, $\mathrm{CHCl}_{3}, \mathrm{CCl}_{4}, \mathrm{C}_{6} \mathrm{H}_{5} \mathrm{Cl}, \mathrm{C}_{6} \mathrm{H}_{6}$,
$\mathrm{C}_{6} \mathrm{H}_{5} \mathrm{CH}_{3}, \quad \mathrm{C}_{6} \mathrm{H}_{4}\left(\mathrm{CH}_{3}\right)_{2}, \quad$ iso- $\mathrm{C}_{4} \mathrm{H}_{9} \mathrm{OH}$, $\mathrm{C}_{4} \mathrm{H}_{9} \mathrm{OH}$, iso- $\mathrm{C}_{5} \mathrm{H}_{11} \mathrm{OH}, \mathrm{C}_{2} \mathrm{H}_{4} \mathrm{Cl}_{2}$ were used. The extractability of the complexes was evaluated by the distribution coefficient and the degree of extraction. The best extractants were $\mathrm{CHCl}_{3}, \mathrm{C}_{2} \mathrm{H}_{4} \mathrm{Cl}_{2}$ and $\mathrm{C}_{6} \mathrm{H}_{5} \mathrm{Cl}$. All further studies were carried out with $\mathrm{CHCl}_{3}$ (extraction ratio (R,\%) $\mathrm{R}=98.3-98.6 \%)$. The concentration of cobalt and nickel in the organic phase was determined using 2-nitroso1-naphthol and dimethylglyoxime [20] respectively, through the photometric measurements after the back extraction, and the aqueous phase was determined by the difference. 


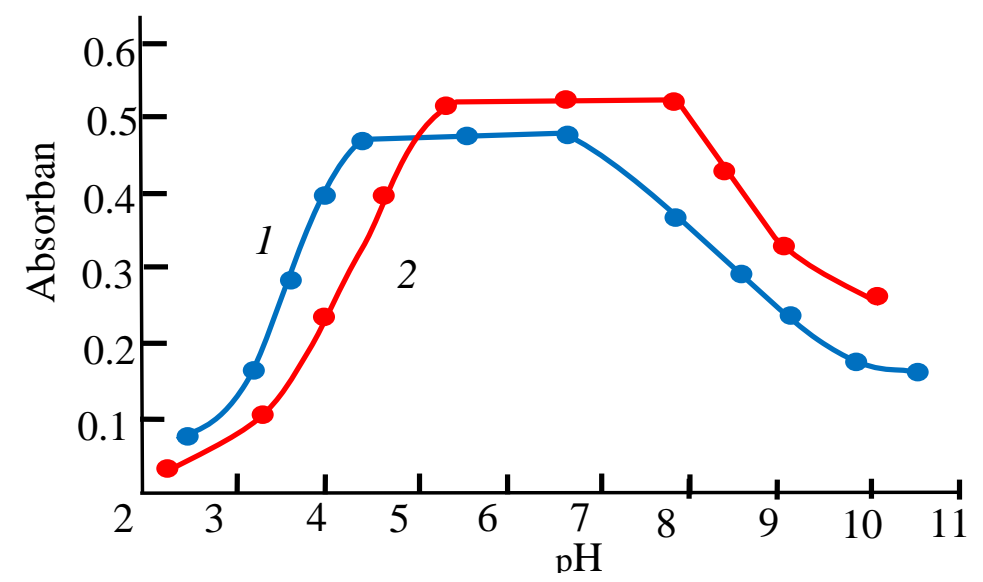

Fig. 1. Absorbance of mixed ligand complexes as a function of the $\mathrm{pH}$ of the aqueous phase: Ni- HNTPh-DPG (curve 1) and Co-HNTPh-DPG (curve 2). $\mathrm{C}_{\mathrm{Co}(\mathrm{II})}=1.7 \times 10^{-5} \mathrm{~mol} \mathrm{~L}^{-1}, \mathrm{C}_{\mathrm{Ni}}=3.5 \times 10^{-5} \mathrm{~mol} \mathrm{~L}^{-1}, \mathrm{C}_{\mathrm{HNTPh}}=(1.2-$ $2.0) \times 10^{-3} \mathrm{~mol} \mathrm{~L}^{-1}, \mathrm{C}_{\mathrm{DPG}}=(2.0-2.5) \times 10^{-3} \mathrm{~mol} \mathrm{~L}^{-1}, \lambda=490$ and $590 \mathrm{~nm}$.

Electronic Absorption Spectra. The spectra of the MLC of Me (II)-HNTPh-DPG extracted in chloroform are shown in Fig.2. Co-HITP-DPG cobalt complex absorption is higher than that of the Ni-HITP-DPG nickel complex. The maximum values are recorded at $560 \mathrm{~nm}$ for Co (II) compounds and at $480 \mathrm{~nm}$ for Ni (II) compounds.

All colour reactions were very contrast, since the initial solutions are colourless $\left(\lambda_{\max }\right.$ $($ HNTPh $)=284 \mathrm{~nm})$. Thus, the bathochromic shift is 276-196 nm. The contrast of the reactions was high, i.e. initial reagents are colourless, and the complexes are intensely coloured.
Effect of reagent concentration. The effect of shaking time. The optimum concentrations of HNTPh and DPG are shown in Table 1. For the formation and extraction of MLC, (1.2-2.0) $\times 10^{-3} \mathrm{M}$ HNTPh and (2.0-2.5) $\times 10^{-3} \mathrm{M}$ DPG are required.

MLC II (II) with HNTPh and DPG are stable in aqueous and organic solvents and do not decompose for two days or for a month after extraction. The effect of shaking time in the course of extraction is shown in Fig. 3. Extracts of Ni-system (curve 1) and Co-system (curve 2) are produced within approximately 2 minutes and 4 minutes respectively. A longer shaking time does not affect absorption.

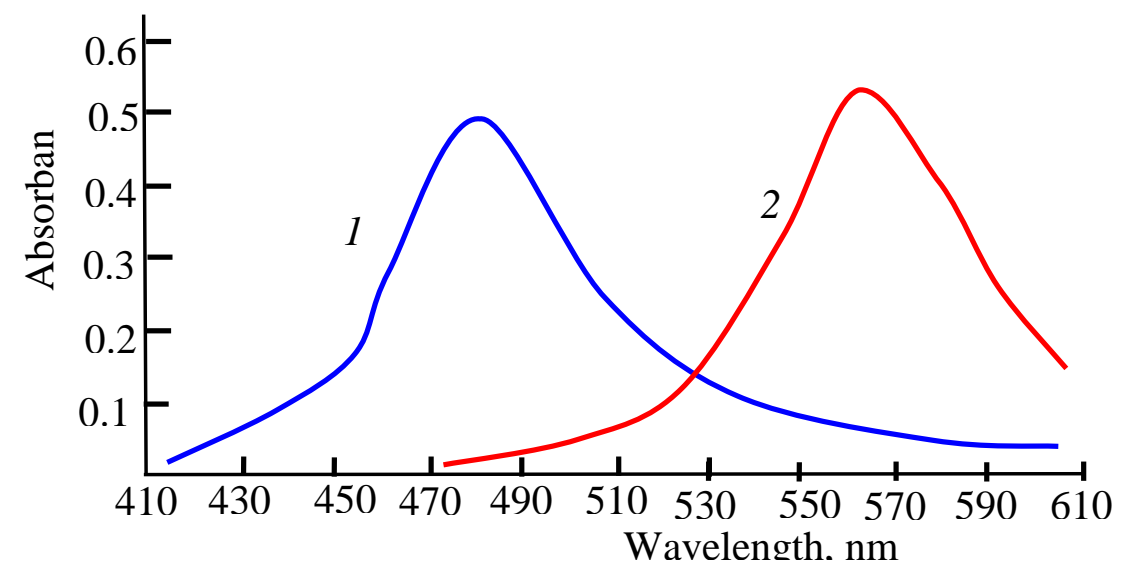

Fig. 2. Absorption spectra of the complexes: Ni-HNTPh-DPG (curve 1) and Co-HNTPh-DPG (curve 2). $\mathrm{C}_{\mathrm{Co}(\mathrm{II})}=$ $1.7 \times 10^{-5} \mathrm{~mol} \mathrm{~L}^{-1}, \mathrm{C}_{\mathrm{Ni}(\mathrm{II})}=3.5 \times 10^{-5} \mathrm{~mol} \mathrm{~L}^{-1}, \mathrm{C}_{\mathrm{HNTPh}}=(1.2-2.0) \times 10^{-3} \mathrm{~mol} \mathrm{~L}^{-1}, \mathrm{C}_{\mathrm{DPG}}=(2.0-2.5) \times 10^{-3} \mathrm{~mol} \mathrm{~L}^{-1}, \mathrm{pH}$ 4.5-6.8 and $\mathrm{pH}$ 5.5-7.9, $\lambda=490$ and $590 \mathrm{~nm}$. 


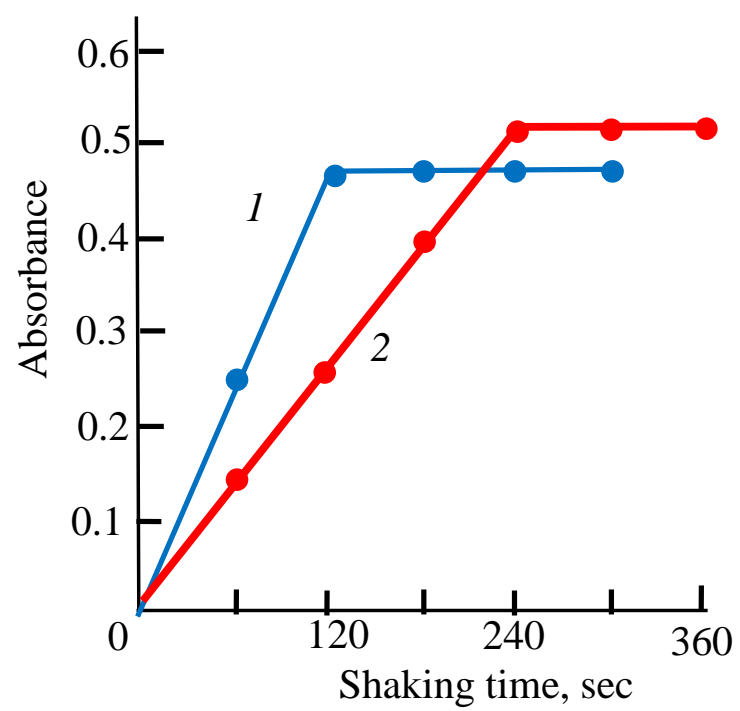

Fig. 3. Effect of shaking time on the absorbance: Ni- HNTPh-DPG (curve 1) and Co- HNTPh-DPG (curve 2). $\mathrm{C}_{\mathrm{Co}(\mathrm{II})}=1.7 \times 10^{-5} \mathrm{~mol} \mathrm{~L}^{-1}, \mathrm{C}_{\mathrm{Ni}(\mathrm{II})}=3.5 \times 10^{-5} \mathrm{~mol} \mathrm{~L}^{-1}, \mathrm{C}_{\mathrm{HNTPh}}=(1.2-2.0) \times 10^{-3} \mathrm{~mol} \mathrm{~L}^{-1}, \mathrm{C}_{\mathrm{DPG}}=$ $(2.0-2.5) \times 10^{-3} \mathrm{~mol} \mathrm{~L}^{-1}$, pH 4.5-6.8 and pH 5.5-7.9, $\lambda=490$ and $590 \mathrm{~nm}$.

Table 1. Optimum operating conditions

\begin{tabular}{|l|c|c|c|c|c|c|}
\hline \multicolumn{1}{|c|}{ Extraction system } & $\begin{array}{c}\text { Extraction } \\
\text { time, s }\end{array}$ & $\mathrm{pH}$ & $\begin{array}{c}\mathrm{C}_{\text {HITP, }} \\
\text { mol L-1 }^{-1}\end{array}$ & $\begin{array}{c}\mathrm{C}_{\mathrm{Am}}, \\
\text { mol L }^{-1}\end{array}$ & $\begin{array}{c}\lambda_{\max }, \\
\mathrm{nm}\end{array}$ & $\begin{array}{c}\Delta \lambda_{\max } \\
\mathrm{nm}\end{array}$ \\
\hline $\mathrm{Ni}(\mathrm{II})-\mathrm{HNTPh}-\mathrm{DPG}-\mathrm{H}_{2} \mathrm{O}-\mathrm{CHCl}_{3}$ & 120 & $4.5-6.8$ & $1.2 \times 10^{-3}$ & $2.0 \times 10^{-3}$ & 480 & 196 \\
\hline $\mathrm{Co}(\mathrm{II})-\mathrm{HNTPh}-\mathrm{DPG}-\mathrm{H}_{2} \mathrm{O}-\mathrm{CHCl}_{3}$ & 240 & $5.5-7.9$ & $2.0 \times 10^{-3}$ & $2.5 \times 10^{-3}$ & 560 & 276 \\
\hline
\end{tabular}

Composition of complexes and suggested formulae. The molar ratios between the components of the MLC were found by several methods: relative yield method, straight line method and equilibrium shift method [21]. The results suggest the complex composition of 1:2:2 (Me : HNTPh : DPG).

The results obtained, some conclusions [3-5] and our previous experience with identical systems suggest that Co (II) was oxidised to Co (III) by the atmospheric oxygen during the complex formation. İ acidic medium, HNTPh exhibit reducing properties. Hence, we are inclined to suggest the following formula of the ternary compound: $\left[\mathrm{Me}(\mathrm{HNTPh})_{2}\right](\mathrm{DPGH})_{2}$; in the formula DPG is in its protonated form $\left(\mathrm{DPGH}^{+}\right)$.
The existence of clearly defined absorption bands at $2410-2415 \mathrm{~cm}^{-1}$ in the IR-spectrum of the complex indicates the coordination of the DPG in the protonated form [22]. The disappearance of the band at $2580 \mathrm{~cm}^{-1}$, characteristic for the spectrum of HNTPh, and the appearance of corresponding bands in the spectrum of the complex which are shifted toward lower frequency, suggests that sulphur atoms are involved in complex formation. The observed decrease in the intensity of the absorption bands at 3200-3600 $\mathrm{cm}^{-1}$ with a maximum at $3460 \mathrm{~cm}^{-1}$ and the appearance of a broad band in the region of 3050-3150 $\mathrm{cm}^{-1}$ shows the involvement of hydroxyl group in the formation of a coordination bond. Proceeding from the obtained data, we propose the following structure for the extracted ternary complex: 
<smiles>[NH2+]=C(Nc1ccccc1)Nc1ccccc1</smiles>

Equilibrium constants. Several processes should be taken into account in the system of $\left[\mathrm{Me}(\mathrm{HNTPh})_{2}\right]^{2-},\left(\mathrm{DPGH}^{+}\right)_{2}$, water and chloroform:

$$
\beta=\frac{\left[M(H I T P)_{2}\right](A m H)}{\left[M(H I T P)_{2}\right]^{2-} \times\left[\left(A m H^{+}\right)_{2}\right]}
$$

2) Distribution of the complexes between the aqueous and the organic phase

$$
\left\{\left[\mathrm{Me}(\mathrm{HNTPh})_{2}\right](\mathrm{DPGH})_{2}\right\}_{\mathrm{aq}} \leftrightarrow\left\{\left[\mathrm{Me}(\mathrm{HNTPh})_{2}\right](\mathrm{DPGH})_{2}\right\}_{\text {org }}
$$

with the distribution constants

$$
K_{D}=\frac{\left[M e(H N T P h)_{2}\right](D P G H)_{o r g}}{\left[\left[M e(H N T P h)_{2}\right](D P G H)_{2}\right]_{a q}}
$$

3) Extraction of the ternary complexes from water into chloroform

$$
\left[\mathrm{Me}(\mathrm{HITP})_{2}\right]^{2-} \text { aq }+\left(\mathrm{DPGH}^{+}\right)_{2} \text { aq } \leftrightarrow\left\{\left[\mathrm{Me}(\mathrm{HNTPh})_{2}\right](\mathrm{DPGH})_{2}\right\}_{\text {org }}
$$

with the extraction constants

$$
K_{e x}=K_{D}+\beta=\frac{\left[\left[M e(H N T P h)_{2}\right](D P G H)\right]_{o r g}}{\left[\left[M e(H N T P h)_{2}\right]^{2-}\right]_{a q} \times\left[\left(D P G H^{+}\right)_{2}\right]_{a q}}
$$

The constants of the distribution $K_{D}$ were determined by comparison of the absorbance values obtained after single extraction under the optimum conditions $\left(\mathrm{A}_{1}\right)$ and the triple extraction $\left(A_{3}\right): K_{D}=A_{1} /\left(A_{3}-A_{1}\right)$. The extraction constants were calculated by the equation $K_{\mathrm{ex}}=\beta+\mathrm{K}_{\mathrm{D}}$. The obtained values are shown in Table 2.

Table 2. Values of the extraction constants $\left(\mathrm{K}_{\mathrm{ex}}\right)$, distribution constants $\left(\mathrm{K}_{\mathrm{D}}\right)$, association constants ( $\beta$ ) and recoveries (R\%) for the Me(II)-HNTPh-DPG-water-chloroform systems

\begin{tabular}{|c|c|c|c|c|}
\hline Extraction system & $\lg \beta$ & $\operatorname{lgK} \mathrm{D}_{\mathrm{D}}$ & $\lg \mathrm{K}_{\mathrm{ex}}$ & $\mathrm{R} \%$ \\
\hline $\mathrm{Co}(\mathrm{II})-\mathrm{HNTPh}-\mathrm{DPG}-\mathrm{H}_{2} \mathrm{O}-\mathrm{CHCl}_{3}$ & $8.59 \pm 0.2$ & $1.86 \pm 0.01$ & $10.56 \pm 0.21$ & 98.3 \\
\hline $\mathrm{Ni}(\mathrm{II})-\mathrm{HNTPh}-\mathrm{DPG}-\mathrm{H}_{2} \mathrm{O}-\mathrm{CHCl}_{3}$ & $9.62 \pm 0.01$ & $1.92 \pm 0.02$ & $11.64 \pm 0.03$ & 98.6 \\
\hline
\end{tabular}

Influence of interfering ions. To evaluate the complex applicability for photometric determination of cobalt and nickel, we examined the influence of foreign ions and reagents. The results showed that great excesses of alkali, alkali earth, and rare earth elements, as well as $\mathrm{NO}^{3-}, \mathrm{ClO}^{4-}, \mathrm{SO}_{4}{ }^{2-}$ and $\mathrm{CH}_{3} \mathrm{COO}{ }^{-}$do not interfere in the 
determination of cobalt and nickel with HITP and Am. Interference of most cations is masked through adding complexone III. Tartrate has the property of masking milligram quantities of Ta, Ti, W and Mo. $\mathrm{Zr}$ and $\mathrm{Cu}$ are masked by fluoride ion and thiourea, respectively.
Beer's law and analytical characteristics. The validity of the Beer's law was checked at optimum conditions (Table 1). Equations of the obtained straight lines and some important characteristics concerning the application of the ternary complexes for extractive-spectrophotometric determination of $\mathrm{Co}(\mathrm{II})$ and $\mathrm{Ni}(\mathrm{II})$ are listed in Table 3.

Table 3. Analytical characteristics

\begin{tabular}{|l|c|c|}
\hline \multicolumn{1}{|c|}{ Characteristic } & Co- HNTPh-DPG & Ni- HNTPh-DPG \\
\hline Apparent molar absorptivity $(\varepsilon), \mathrm{L} \mathrm{mol}^{-1} \mathrm{~cm}^{-1}$ & $3.30 \times 10^{4}$ & $2.64 \times 10^{4}$ \\
\hline Adherence to Beer's law, $\mu \mathrm{g} \mathrm{mL} \mathrm{mL}^{-1}$ & $0.8-20$ & $0.7-18$ \\
\hline Equation of straight line & $0.1252 \mathrm{X}+0.054$ & $0.149 \mathrm{x}+0.02$ \\
\hline Coefficient of correlation & 0.9993 & 0.9981 \\
\hline Sandell's sensitivity, $\mathrm{ng} \mathrm{cm}{ }^{-2}$ & 0.00746 & 0.00745 \\
\hline Limit of detection (LOD), $\mu \mathrm{g} \mathrm{mL}^{-1}$ & 14 & 11 \\
\hline Limit of quantification (LOQ), $\mu \mathrm{g} \mathrm{mL}^{-1}$ & 45 & 36 \\
\hline
\end{tabular}

Determination of nickel in magnesium and carnallite. The developed analytical procedure was used to analyze real samples. Two replicates of metallic magnesium and two samples of carnallite were subjected to analysis. Results are shown in Table 4; their reliability was verified by the added-recovered method.

Dissolution of magnesium. A 0.5-0.6 g sample of magnesium was carefully dissolved in $10 \mathrm{~mL}$ of $\mathrm{HNO}_{3}(1: 2)$ and the solution was evaporated to moist salts on an electric heater. After cooling, $3 \mathrm{~mL}$ of water were added to dissolve the salts and $\mathrm{pH}$ was adjusted to $c a .6$ with $\mathrm{NaOH}$. The solution was quantitatively transferred into a $25 \mathrm{~mL}$ calibrated flask; then distilled water was added to the mark.

Dissolution of carnallite. A ca. $2.0 \mathrm{~g}$ sample of carnallite was placed in a $50-\mathrm{mL}$ beaker. $0.5 \mathrm{~mL}$ of a $3 \% \mathrm{NaF}$ solution and 5 $\mathrm{mL}$ of $\mathrm{HNO}_{3}(1: 20)$ were added and the beaker was heated on an electric heater. After cooling, the obtained solution was neutralised with ammonia to $\mathrm{pH} 6$ (universal paper indicator); then it was transferred through a filter paper into a $50 \mathrm{~mL}$ calibrated flask and diluted to the mark with distilled water.

Table 4. Determination of cobalt and nickel in metallic magnesium and carnallite

\begin{tabular}{|c|c|c|c|c|c|c|c|c|}
\hline \multirow{3}{*}{ Sample } & \multicolumn{2}{|c|}{ Found $(\%) \times 10^{-4}$} & \multicolumn{6}{|c|}{ Added-recovered method } \\
\hline & \multirow{2}{*}{$\mathrm{Ni}$} & \multirow{2}{*}{ Co } & \multicolumn{2}{|c|}{ Added (\%) $\times 10^{-3}$} & \multicolumn{2}{|c|}{ Recovered (\%) $\times 10^{-3}$} & \multicolumn{2}{|c|}{ RSD (\%) } \\
\hline & & & $\mathrm{Ni}$ & Co & $\mathrm{Ni}$ & Co & $\mathrm{Ni}$ & Co \\
\hline $1^{\mathrm{a}}$ & $7.65 \pm 0.01$ & $5.12 \pm 0.03$ & 1 & 1 & 1.765 & 6.123 & 1.4 & 1.3 \\
\hline $2^{\mathrm{a}}$ & $7.64 \pm 0.02$ & $5.09 \pm 0.01$ & 1 & 1 & 1.764 & 6.094 & 1.5 & 1.2 \\
\hline $1^{\mathrm{b}}$ & $8.71 \pm 0.01$ & $5.81 \pm 0.04$ & 1 & 1 & 1.871 & 6.812 & 1.3 & 1.4 \\
\hline $2^{b}$ & $8.69 \pm 0.02$ & $5.35 \pm 0.02$ & 1 & 1 & 1.869 & 6.351 & 1.8 & 1.5 \\
\hline
\end{tabular}

\section{CONCLUSIONS}

1. Cobalt (II) nickel (II) form chloroform extractable complexes of mixed ligands with HNTPh and DPG. The anionic part of these

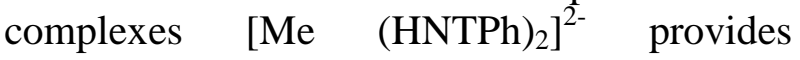

intensive coloring (for the nickel complex $\lambda_{\max }$ $=480 \mathrm{~nm}$ and for the cobalt complex $\lambda_{\max }=$ $560 \mathrm{~nm}$ ) and the bulk of the cationic part 
$\left(\mathrm{DPGH}^{+}\right)$, in turn, guarantees poor solubility in water.

2. The following equilibrium constants and analytical parameters are calculated: extraction constants $\left(\mathrm{K}_{\mathrm{ex}}=10.56-11.64\right)$, association constants $(\beta=8.59-9.62)$, distribution constants $\left(K_{D}=1.86-1.92\right)$, recovery factors $(R=98.3-$ $98.6 \%)$, molar absorptive capacities $(\varepsilon=(2.64-$
3.30) $\times 10^{4}$ ), Sendell sensitivity (SS $=0.00745$ $0.00746 \mathrm{ng} \mathrm{cm}^{-2}$ ), detection limits (LOD $=11$ $14 \mu \mathrm{g} \mathrm{mL} \mathrm{m}^{-1}$ ) and limits of quantitative evaluation $\left(\mathrm{LOQ}=36-45 \mu \mathrm{g} \mathrm{mL}^{-1}\right)$. Analogous values of some above-mentioned characteristics obtained through the use of independent methods go to show the correctness of the experiments performed.

\section{REFERENCES}

1. Verdizade N.A., Amrakhov T.I., Kuliev K.A., Zalov A.Z. 2-hydroxy-5chlorothiophenol as new analytical reagent for determination of $\mathrm{V}(\mathrm{V})$, Mo and W. Zhurnal Analiticheskoj Khimii - Journal of analytical chemistry. 1997, vol. 52, no. 10, pp. 10421046. (In Russian).

2. Kuliyev K.A., Verdizade N. A. Spectroscopic investigation of the complex formation of niobium using 2,6-dithiolphenol and aminophenols. American journal of analytical chemistry. 2015, vol.6, pp.746756.

3. Zalov A.Z., Verdizade N.A. Liquid-Liquid Extraction-Spectrophotometric Determination of Vanadium with 2-Hydroxy-5-Bromothiophenol and Aromatic Amines. Chemistry journal. 2015, vol. 5, no. 4, pp. 54-62.

4. Kuliev K.A., Verdizade N.A., Gadjieva A.B. Liquid-liquid extraction and spectrophotometric determination of molybdenum with 2, 6-dithiolphenol and its derivatives in the presence of hydrophobic amines. Chemistry Journal. 2015, vol. 5, no. 3, pp. 4553.

5. Zalov A.Z., Gavazov K.B. Liquid-liquid extraction-spectrophotometric determination of molybdenum using o-hydroxythiophenols. Journal of advances in chemistry. 2014, vol. 10, no. 8, pp. 3003-3011.

6. Zalov A.Z., Verdizade N.A., Hadjieva A.B. Extraction and spectrophotometric determination of molybdenum with o-hydroxythiophenols and aromatic amines. Pak. J. Anal. Environ. Chem. 2015, vol. 16, no. 1, pp. 16 23.

7. Zalov A.Z., Verdizade N.A. Extractionspectrophotometry determination of tungsten with 2-hydroxy-5-chlorothiophenol and hydrophobic amines. Zhurnal Analiticheskoj Khimii - Journal of analytical chemistry. 2013, vol. 68, no. 3, pp. 212-217. (In Russian).

8. Zalov A.Z., Gavazov K.B. Extractive spectrophotometric determination of nickel with 2-hydroxy-5-iodothiophenol and diphenylguanidine. Chemistry journal. 2014, vol. 4, no. 5, pp. 20-25.

9. Kuliyev K.A., Verdizade N.A., Gadjieva A.B., Mamedova S.A. Spectroscopic investigation complexformation of molybdenum with 2, 6-dithiolphenol and its derivatives in the presence of hydrophobic amines. International journal of chemical studies. 2016, vol. 4, no. 3, pp. 42-48.

10. Kuliyev K.A. Spectroscopic investiqation complex formation of vanadium using 2,6dithiol-4-methylphenol and hudrophob amins. Journal of advances in chemistry. 2015, vol. 11, no. 4. pp. 3487-3497.

11. Kuliyev K.A., Verdizade N.A. Spectroscopic investiqation complex formation of vanadium using 2,6-dithiolphenol and hydrofob amins. American journal of chemistry. 2015, vol. 5, no. 1. pp. 10-18.

12 Zalov A.Z., Verdizade N.A., Jamalova R.I. Extraction-photometric determination of niobium (V) with 2-hydroxy-5-bromthiophenol and hydrophob amines. Azerb.Chem.Journal. 2011, no. 1, pp. 97-102.

13. Zalov A.Z., Amanullayeva G.I. Spectrophotometric determination of cobalt (II) in a liquid-liquid extraction system containing 2- hydroxy-5-iodothiophenol and diphenylguanidine. Journal of applied science. 2016, vol. 2, no. 7, pp. 2 17-225.

14. Zalov A.Z., Gavazov K.B. Extractive spectrophotometric determination of nickel with 2-hydroxy-5-iodothiophenol and 
diphenylguanidine. Chemistry journal. 2014, vol. 4, no. 5, pp. 20-25.

15. Novruzova N.A., Mamedova R.A., Maharramov A.A., Ibrahimova Sh.A., Zalov A.Z., Verdizade N.A., Aliyev S.G. Extractionspectrophotometric study on the complex formation in the cobalt (II) - 4-hydroxy-3thiolbenzoic acid-diphenylguanidine system. International journal of innovative science, engineering \& technology. 2017, vol. 4, no. 6, pp. $2348-7968$.

16. Aliyev S.G., Askerova Z.G., Zalov A.Z. Complex formation in a liquid-liquid extraction system containing nickel (II), 2hydroxy-5-nitrothiophenol and hydrophobic amines. International journal of innovative science, engineering \& technology. 2018, vol. 5, no. 2, pp. 54-64.

17. Zalov A.Z., Gasimova Y.C., Ibrahimova Sh.A. Liquid-liquid extraction and spectrophotometric characterization of some new ternary ion-association complexes of cobalt (II) and nickel (II). Journal of Applied Science. 2016, vol. 2, no. 6, pp. 36-41.

18. Korostelev P.P. Preparation of solutions for chemical analysis works. M.: Publishing house of Academy of Sciences of the USSR. 1964.

19. Kuliev A.M., Aliev S.R., Mamedov F.N., Movsumzade M. Synthesis of aminomethyl derivatives of 2-hydroxy-5-tert-alkylthiophenols and their cleavage by thiols. Zhurnal organicheskoj himii - Russian Journal of Organic Chemistry. 1976, vol. 12, no. 2, p. 426. 20. Marczenko Z., Balcerzak M. Spectrophotometry methods in the UV and visible regions in inorganic analysis. Moskow: Binom Puble, 2007, 711p.

21. Bulatov M.I., Kalinkin I.P. A practical guide to photocolorimetric and spectrophotometric methods of analysis. Leningrad, 1986, 432 p. (İn Russian).

22. Fritz J. S., Schenk G. H. Quantitative analytical chemistry. Boston: Allyn and Bacon. 1974, 356 p.

\title{
ИЗУЧЕНИЕ РЕАКЦИИ КОМПЛЕКСООБРАЗОВАНИЯ КОБАЛЬТА (ІІ) И НИКЕЛЯ (II) С 2-ГИДРОКСИ-5-НИТРОТИОФЕНОЛОМ И ДИФЕНИЛГУАНИДИНОМ
}

\author{
С.Г. Алиев ${ }^{1}$, Р.А. Исмаилов ${ }^{1}$ Ш.А. Ибрагимов ${ }^{2}$, З.Г. Аскерова ${ }^{3}$, А.З. Залов ${ }^{3}$ \\ ${ }^{1}$ Азербайджанский Государственный Университет Нефта и \\ AZ 1000, Баку, пр. Азадльгі16/21, \\ ${ }^{2}$ Бакинский Государственный Университет \\ Аз 1148 Баку, ул. Захида Халилова, 23 \\ ${ }^{3}$ Азербайджанский Государственный Педагогический Университет \\ Аз 1000 Баку, ул. Уз. Гаджибекова, 68; e-mail: zalov1966@mail.ru
}

При взаимодействии кобальта (II) и никеля (II) с 2-гидрокси-5-нитротиофенолом (ГНТФ) и дифенилгуанидином (ДФГ) образуются экстрагируемые хлороформом разнолигандные комплексы (РЛК) $c$ соотночением Ме(II):ГНТФ:ДФГ=1:2:2. Найдены условия экстракционно-фотометрического определения кобальта (II) и никеля (II). Установлено,

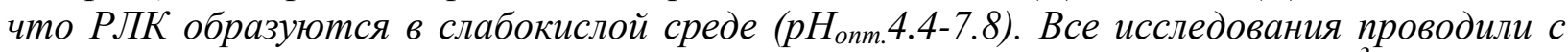

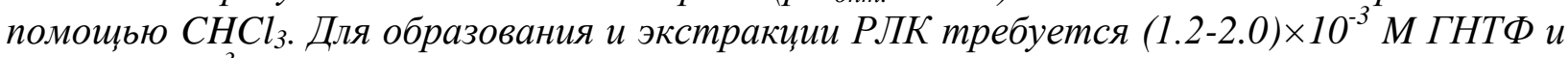
$(2.0-2.5) \times 10^{-3}$ М ДФГ. Максимум в спектре светопоглощения для РЛК кобальта (II) $u$ никеля (II) наблюдается при 560 нм и 480 нм соответственно. Рассчитаны следуюшие химико-аналитические параметры: константы извлечения (K $\left.K_{э x}=10.56-11.64\right)$, константы устойчивости ( $\beta=8.59-9.62)$, константы распределения $\left(K_{D}=1.86-1.92\right)$, коэффициенты извлечения $(R=98.3-98.6 \%)$, молярный коэффициент светопоглощения равен $(2.64 \div 3.30) \times 10^{4}$.

Ключевые слова: кобальт, никель, 2-гидрокси-5-нитротиофенол, хлороформ 


\title{
KOBALT (II) VӘ NIKELIN (II) 2-HIDROKSI-5-NITROTIOFENOL VӘ DIFENILQUANIDINLO KOMPLEKSOMOLOGOLMO REAKSIYASININ TODQIQI
}

\author{
S.Q. Oliyev ${ }^{1}$, R.A. Ismayılova ${ }^{1}$, S..A. İbrahimova ${ }^{2}$, Z.G. Osgərova ${ }^{3}$, Ә. Z.Zalov ${ }^{3}$ \\ ${ }^{3}$ Azarbaycan Dövlat Heft va Sanaye Universiteti \\ 1000, Bakl, Azadlig pr.,16/21, \\ ${ }^{2}$ Bakı Dövlat Universiteti \\ Az 1148 Bakl, Zahid Xalilov küçs, 23, \\ ${ }^{3}$ Azarbaycan Dövlat Pedaqoji Universiteti \\ Az 1000 Bakı, Uz. Hacıbəyov küç., 68; \\ e-mail: zalov1966@mail.ru
}

Kobalt (II) va nikel (II) 2-hidroksi-5-nitrotiofenol (HNTF) va difenilquanidin (DFQ) ila qarşılıqlı tasirdə olaraq xloroformla yaxşı ekstraksiya olunan müxtəlif liqandlı kompleks birlaşmə (MLK) əməla gətirir (Me(II):HNTF:DFQ =1:2:2). Kobalt (II) və nikelin (II) ekstraksiya-fotometrik təyininin optimal şəraiti müəyyən edilmişdir. MLK zaif turş mühitdə amala galir ( $\mathrm{pH}_{\text {opt. }}$ 4.4- 7.8). On yaxşı ekstragent kimi $\mathrm{CHCl}_{3}$ müayyan edilmişdir. MLK amala galmasi va ekstraksiyası üçün $(1.2-2.0) \times 10^{-3}$ M HNTF va (2.0-2.5) $\times 10^{-3}$ M DFQ tələb olunur. Kobalt (II) və nikelin (II) MLK müvafiq olaraq 560 və $480 \mathrm{~nm}$-də maksimum işıq udur. Bazi kimyəvi- analitik sabitlar hesablanmışdır: tarazlıq sabiti $\left(K_{e x}=10.56-11,64\right)$ davamlılıq sabiti $(\beta=8.59-9.62)$, paylanma sabiti $\left(K_{D}=1.86-1.92\right)$ ekstraksiya dəracəsi $(R=98.3-98.6 \%)$, molyar işıqudma omsalı $\left(\varepsilon=(2.64-3.30) \times 10^{4}\right.$.

Açar sözlor: kobalt, nikel, 2-hidroksi-5-nitrotiofenol, difenilquanidin, xloroform 